\title{
Metalotolerance Capacity of Autochthonous Bacteria Isolated From Industrial Waste Effluent
}

\author{
Olusola N. Majolagbe ", Elijah A. Adebayo, Abiodun Ayandele, Louis Ezediuno \\ Microbiology Unit, Department of Pure and Applied Biology, Ladoke Akintola University of Technology. P.M.B 4000, Ogbomoso, Oyo State, Nigeria.
}

Received $05^{\text {th }}$ Feb. 2017, Accepted $29^{\text {th }}$ Dec. 2017

DOI: 10.2478/ast-2018-0003

*Corresponding author

O.N. Majolagbe E-mail: oomajolagbe@lautech.edu.ng, olusola.nat@gmail.com. Tel: $+234-8038360759$

\begin{abstract}
Microbes play significant roles in remediation of heavy metal polluted industrial effluent using the mechanisms of biosorption and bioaccumulation. In the present study, six heavy metal resistant autochthonous bacteria species namely Bacillus cereus, B. megaterium, B. subtilis, Flavobacterium aquatile, Pseudomonas flourescens and Pseudomonas putida were isolated from effluent samples collected from Paper-mill industry (PMI), Paints and Chemicals Industry (PCI), and Steel-rolling Industry (SRI). The isolates were studied for their heavy metal tolerant capacities at different aqueous salt concentrations. Elemental analysis of the industrial effluent samples collected indicated the presence of heavy metals such as Copper $\left(\mathrm{Cu}^{2+}\right)$, Manganese $\left(\mathrm{Mn}^{2+}\right)$, Iron $\left(\mathrm{Fe}^{2+}\right)$ and Lead $\left(\mathrm{Pb}^{2+}\right)$ at varying concentrations in $\mu \mathrm{g} / \mathrm{ml}$. Generally, there were variations in the minimum inhibitory concentrations (MIC) of the heavy metal salt to each of the bacteria understudy. The MIC value of each of the bacterial isolates to aqueous solution of $\mathrm{Cu}_{2} \mathrm{SO}_{4}$ showed that $B$. megaterium, B. subtilis, Pseudomonas flourescens and Pseudomonas putida had the same MIC value of $20 \pm 1.5 \mu \mathrm{g} / \mathrm{mL}$ while Bacillus cereus and Flavobacterium aquatile had MIC values of $13 \pm 1.3 \mu \mathrm{g} / \mathrm{mL}$ and $25 \pm 2.1 \mu \mathrm{g} / \mathrm{mL}$ respectively. This variation was also noticeable in aqueous salts of $\mathrm{Mn}_{2} \mathrm{SO}_{4}, \mathrm{Fe}_{2} \mathrm{SO}_{4}$ and $\mathrm{Pb}_{2} \mathrm{SO}_{4}$. The bacteria isolates showed sensitivity to heavy metals with increasing zone of inhibition as concentration increased with each isolate showing varying degree of metalotolerance. The effectiveness of the autochthonous bacteria as a means to bio-augment the remediation of heavy metal polluted industrial effluent was further proven and recommended.
\end{abstract}

Keywords: Industrial effluent; Autochthonous bacteria; Metalotolerance; Waste. 


\subsection{Introduction}

Our environment faces careless increase in pollution level on account of uncontrolled increase in population, urbanization, industrialization and anthropogenic activities (Hanif et al., 2005; Benson, 2006).Among the various pollutants, heavy metal contamination is one of the most critical environmental challenges in the twenty first century. Modern industries are majorly responsible for this problem of pollution as they continually and indiscriminately release pollutants into the ecosystem. Industrial effluents contain a large variety of toxic compounds; of which heavy metals with potentials to reach hazardous levels when accumulated in the environment is typically found (Nriagu and Pacyna, 1988). Heavy metals are elements with specific gravity equal to and greater than 5.0 and relative atomic weights ranging from 63.5 to 200.6, they are usually hazardous toxicants to humans, animals and the environment at a certain level.

Due to increase application of heavy metals in industrial processes, there is a steady rise in environmental pollution caused by heavy mental contamination from these processes. The major sources of heavy metals contaminants are indigenous waste waters and effluent from pharmaceutical industries, mines, metal processing industries, leather tanneries, pesticides, organic chemicals, rubber and plastics industries, lumber and wood production sites (Ansari et al.,2004; Vullo et al., 2005).Heavy metals contamination spreads in the environment by run-offs which join other water bodies thereby contaminating these water sources (Downstream processes from industrial sites). Agricultural activities such as using agrochemicals and sewage sludge on farm land and cultivated plants also add substantial amount of these toxic metals to soils (Duxbury, 1994).

The problems of heavy metal as a pollutant cannot be overly emphasised because of its toxic nature to human and animal health and the general wellbeing of the ecosystem, this is because of their high occurrence as a toxicant, low solubility in the environment and, the classification of numerous members of these group as mutagens and carcinogens (Alloway, 1995). Heavy metals causing critical concern to human health and wellbeing are arsenic, mercury, lead, cadmium, chromium, copper and zinc (Lazrova et al., 2005). It is estimated that more than a billion people are one way or the other subjected to elevated concentration of heavy metals and metalloids and millions of people all over the world may be suffering from sub-clinical metal poisoning (Nriagu, 1988; Nriagu and Pacyna 1988). Only recently about some few decades ago that increasing recognition of the health hazards and environmental consequences of heavy metals release into the environment has impelled the necessity for the decontamination of industrial effluent prior to release into natural water bodies.

Three types of metals are of more interest in the heavy metal pollution and these include:

- $\quad$ Toxicant such as Arsenite (As), Cadmium (Cd), Lead $(\mathrm{Pb})$, Mercury $(\mathrm{Hg})$, Chromium (Cr), Nickel
- $\quad(\mathrm{Ni})$,Copper (Cu), Cobalt (Co), Zinc (Zn), Tin (Sn) etc.

- Precious metals such asGold (Au), Silver (Ag), Palladium (Pd), Platinum (Pt), Ruthenium (Ru)etc.

- And radio nuclides such as Uranium (U),Radium (Ra),Thorium (Th), Americium, etc (Wang and Chen, 2006).

Physicochemical methods for removal of heavy metals from waste waters such as lime coagulation ion exchange, reverse osmosis, solvent extraction, and chemical precipitation cost a lot and these unfortunately do not remove heavy metals from waste water to the desired level (Kadirvelu et al., 2001). It was only recent times that a new scientific era developed a technique that could help decontaminate and recover heavy metals from industrial wastes, this is the process of adopting and adapting natural biological processes to remediate the problems of heavy metals in industrial wastes before releasing the wastes into the natural environment. Biological method is an innovative technology that has been ever present for heavy metal polluted wastewaters remediation but was recognised only recently. Since microorganism have adapted survival tactics in habitats polluted with heavy metals, their different heavy metal degrading/detoxifying mechanisms such as bio-sorption, bioaccumulation, bio-mineralization or biotransformation can be applied either in situ or ex situ to design bioremediation processes that is economically viable (Crawford and Crawford, 1995; Lin and Lin,2005; Munoz, et al., 2006; Umrania, 2006).The application of Bio-sorption in heavy metal remediation of waste water makes the subsequent recovery of these metals easier and economically feasible. The application of bio-sorption exploits the characteristics of microbes to adsorb metals, this can be applied commercially.

Since heavy metal tolerant microorganism can be found in heavy metal contaminated sites and industrial effluent, samples from the effluent and sites can be taken and analysed to identify the metals and the microbial population present in them. Hence, this paper investigates autochthonous microbes isolated from effluent samples and their capacity for the removal of heavy metals in vitro using aqueous heavy metal salts solutions at different concentrations.

\subsection{Materials and Methods}

\subsection{Sample Collection}

Collections of samples were carried out in three locations in South-Western Nigeria; this is as follows: Paper-mill industry (PMI), Ikeja Industrial Estate, Ikeja, Lagos State, Paints and Chemicals Industry (PCI), Agege, Lagos State and Steel-rolling Industry (SRI) at Osogbo, Osun State. The samples were collected into sterile $50 \mathrm{ml}$ bottles, taken to the laboratory and maintained at $4{ }^{\circ} \mathrm{C}$ to stop further biological activity. The pHs of the effluent samples was determined using $\mathrm{pH}$ meter. 
2.2 Isolation and identification of Metalotolerant autochthonous bacteria from industrial effluent

In isolating bacteria from the industrial effluents, samples were cultured on nutrient agar media by serial dilution. $1 \mathrm{~mL}$ of each sample of effluent was diluted serially with $9 \mathrm{~mL}$ of distilled water to a concentration of $10^{-1}$ to $10^{-5}$ in separate test tubes. Pour plate method was used by introducing $100 \mu \mathrm{L}$ of the serial diluents effluent of concentration $10^{-3}, 10^{-4}$ and $10^{-5}$ respectively into separate plates before introducing the nutrient agar media, then incubated at $35{ }^{\circ} \mathrm{C}$ for 24 to $72 \mathrm{~h}$. Isolates were sub-cultured onto fresh nutrient agar media and were characterized and identified based on their morphology, cultural, macroscopic andmicroscopic appearanceandtheir biochemical metabolic reactions.

\subsection{Heavy metal determination by Atomic Absorption Spectroscopy}

The concentrations heavy metals in each of the effluent samples were analysed using Atomic Absorption Spectroscopy (AAA) (Saxena, 1998; APHA, 1998). In doing this, samples were digested, and ultra-pure distilled water was added to make up to $30 \mathrm{ml}$ of each sample that was dispensed into vials for the analyses. The elements determined include: Copper, Lead, Manganese, Iron, and Chromium.

\subsection{Determination of heavy metal-resistant bacteria}

This experiment was carried out using the method of Hassen et al (1998). Aqueous solutions of the determined heavy metals salts $\left(\mathrm{CuSO}_{4}, \mathrm{PbNO}_{3}, \mathrm{FeSO}_{4}\right.$ and $\left.\mathrm{MnCl}_{2}\right)$ were prepared. Wells were aseptically dug into freshly inoculated Nutrient Agar plates and to each well, $100 \mu \mathrm{L}$ of each prepared metal salt solution were introduced, the plates were incubated for $24 \mathrm{~h}$ at a temperature of $37{ }^{\circ} \mathrm{C}$. The minimum inhibitory concentration (MIC) of each of the metal salts against each of the tested isolates were observed and recorded.

\subsection{Results and Discussion}

The adverse environmental impact of heavy metal pollution on human, animals and plant health and the general well-being of the environment should be swiftly and seriously dealt with by applying bioremediation techniques to abate the lethal levels of heavy metals in sites that are contaminated and on industrial wastes before they are released into the environment (Pandi, et al., 2009). From our work, elemental analysis of the industrial effluent samples collected indicated the presence of heavy metals such as $\mathrm{Cu}^{2+}, \mathrm{Mn}^{2+}, \mathrm{Fe}^{2+}$ and $\mathrm{Pb}^{2+}$ at varying concentrations in $\mu \mathrm{g} / \mathrm{ml}$ as shown in Table 1 . In PCI and PMI effluent samples, $\mathrm{Fe}^{2+}$ had the highest heavy metal concentration of $0.4 \mu \mathrm{g} / \mathrm{mL}$ and $0.5 \mu \mathrm{g} / \mathrm{mL}$ and least is $\mathrm{Mn}^{2+}(0.02 \mu \mathrm{g} / \mathrm{mL})$ and $\mathrm{Pb}^{2+}(0.05 \mu \mathrm{g} / \mathrm{mL}$ ) respectively. SRI also showed a similar trend of result with $\mathrm{Fe}^{2+}$ having the highest concentration $(0.4 \mu \mathrm{g} / \mathrm{mL})$ and least is $\mathrm{Pb}^{2+}$ $(0.02 \mu \mathrm{g} / \mathrm{mL})$. This indicates that $\mathrm{Fe}^{2+}$ is a prominent heavy metal present in PCI and SRI during industrial production processes.
Table 1: Heavy metal concentration. present in industrial effluent

\begin{tabular}{lrrr}
\hline Heavy metal & PCI & $\begin{array}{r}\text { PMI } \\
(\mu \mathrm{g} / \mathrm{ml})\end{array}$ & $\begin{array}{c}\text { Source of effluent } \\
\text { SRI } \\
(\mu \mathrm{g} / \mathrm{ml})\end{array}$ \\
$\mathrm{Mn}^{2+}$ & $(\mu \mathrm{g} / \mathrm{ml})$ & 0.40 & 0.03 \\
$\mathrm{Fe}^{2+}$ & 0.02 & 0.50 & 0.40 \\
$\mathrm{~Pb}^{2+}$ & 0.40 & 0.05 & 0.02 \\
$\mathrm{Cu}^{2+}$ & 0.03 & 0.40 & 0.20 \\
& 0.20 & &
\end{tabular}

Paint \& Chemical Industry PMI: Paper mill Industry SRI: Steel-rolling Industry.

Heavy metal concentrations in the environment have been reported not only to be hazardous, but as threat to the biotic component of the ecosystem. Adverse effects of heavy metals comprise, bio-accumulation in the tissue of many organisms, this leads to bio-magnification of toxic metal in the tissue of living organisms (Panikar et al., 2003) from which other adverse effects such as immunosuppression, carcinogenicity (Peakall, 1992), neurotoxicity which has high frequency among children (Cohen, 2005), enzyme inhibition, especially inhibition of some very important enzymes associated with synthesis of vital biomolecules develops. In this study, six bacteria species were isolated from all the industrial effluents used in this study namely: Bacillus cereus (Bc), B. megaterium (Bm), B. substilis $(B s)$, Pseudomonas flourescens (Pf), P. putida (Pp) and Flavobacterium aquatile (Fa). Shukla et al (2007) in his work, reported to have isolated four chromate-tolerant bacteria strains which exhibited multiple metal and antibiotic resistances, Shukla's isolated bacterial strains in his paper shukla et al (2007) was reported to accumulated chromate to a high degree demonstrating that they have very promising potential in detoxification and recovery of chromate (Shukla, et al., 2007). Of all the bacterial isolated for this research, only Bacillus spp. was dominant (Table 2).

Table 2: Microbial composition of effluent samples

\begin{tabular}{lc} 
Sources of effluent & \multicolumn{1}{c}{ Microbes present } \\
PCI & $\begin{array}{c}\text { Pseudomonas fluorescence, } \text { P. putida } \\
\text { PMI } \\
\text { BRI }\end{array}$ \\
Bacillus cereus, $\quad$ B. megaterium
\end{tabular}

The bacteria were characterized and identified using colonial morphology, microscopy and biochemical tests. The microbial isolates showed varying degree of tolerance to aqueous heavy metal salts using plate diffusion method at different concentration as shown in figures 1-4. Kao et al (2008) carried out similar work when him and his team used a MerP expressing recombinant Escherichia coli which originated from Gram-positive (B. cereus) and Gram-negative (Pseudomonas sp.) were used to adsorb Nickel, Zinc and Chromate in aqueous solution (Kao et al., 2008). Figure 1 showed the minimum inhibitory concentration (MIC) of each of the bacterial isolates to aqueous solution of $\mathrm{Cu}_{2} \mathrm{SO}_{4}$ with $\mathrm{Bm}, \mathrm{Bs}$, Pf and $\mathrm{Pp}$ having the same MIC value of 2 $\pm 1.5 \mu \mathrm{g} / \mathrm{ml}$ while Bc and Fa had MIC values of $13 \pm 1.3 \mu \mathrm{g} / \mathrm{mL}$ and $25 \pm 2.1 \mu \mathrm{g} / \mathrm{mL}$ respectively. MIC values of aqueous solution 
of $\mathrm{Mn}_{2} \mathrm{SO}_{4}$ to the microbial isolates showed that $\mathrm{Bm}, \mathrm{Bs}, \mathrm{Pp}$ had MIC values of $100 \pm 6.7 \mu \mathrm{g} / \mathrm{mL}, \mathrm{Bc}$ and $\mathrm{Fa}$ had MIC values of 50 $\pm 5.5 \mu \mathrm{g} / \mathrm{mL}$ while Pf had MIC value of $20 \pm 2.6 \mu \mathrm{g} / \mathrm{mL}$ (Fig. 2).

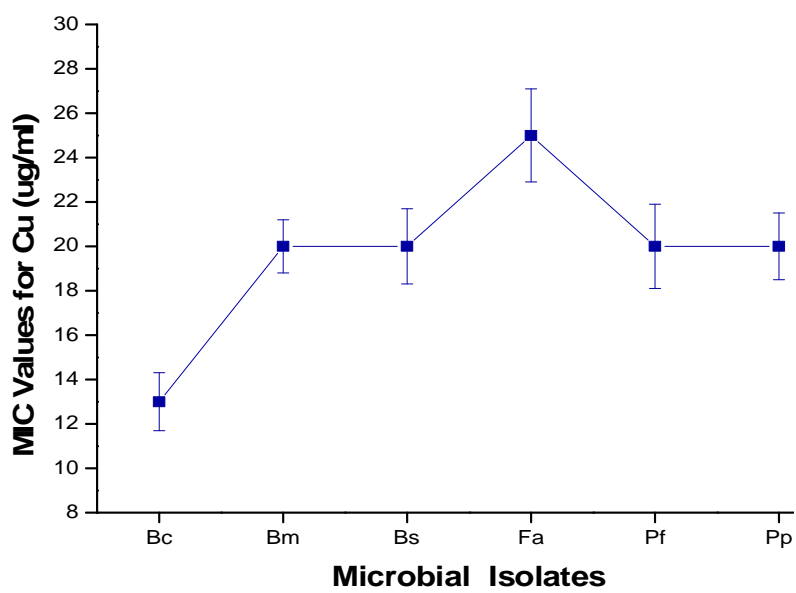

Fig. 1: MIC values of microbial isolates to aqueous salts of $\mathrm{Cu}_{2} \mathrm{SO}_{4}$.

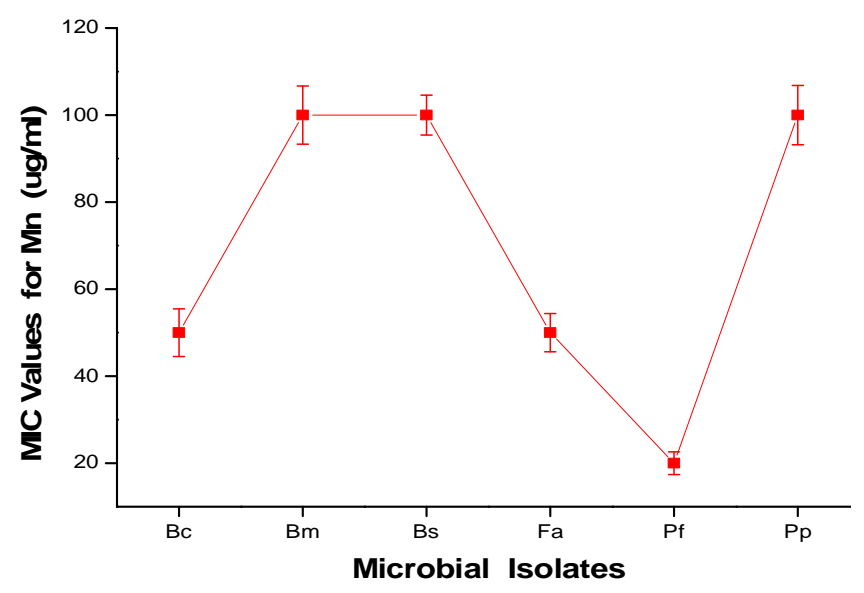

Fig.2: MIC values of microbial isolates to aqueous salts of $\mathrm{Mn}_{2} \mathrm{SO}_{4}$

Figure 3 also shows the MIC values for $\mathrm{Fe}_{2} \mathrm{SO}_{4}$ in which $\mathrm{Bm}$, and Pp had MIC values of $25 \pm 2.5 \mu \mathrm{g} / \mathrm{mL}$, Bs and Fa had MIC values of $50 \pm 3.7 \mu \mathrm{g} / \mathrm{mL}$, while $\mathrm{Bc}$ and Pf had MIC values of $100 \pm 5.7$ $\mu \mathrm{g} / \mathrm{mL}$ and $25 \pm 1.8 \mu \mathrm{g} / \mathrm{mL}$ respectively. The MIC values of the bacterial isolates to $\mathrm{Pb}_{2} \mathrm{SO}_{4}$ is as shown in Figure 4 in which $\mathrm{Bc}$, $\mathrm{Bm}$, Bs and Pp had MIC values of $20 \pm 2.5 \mu \mathrm{g} / \mathrm{mL}$ while $\mathrm{Fa}$ and Pf had MIC values of $13 \pm 1.5 \mu \mathrm{g} / \mathrm{mL}$ and $50 \pm 4.2 \mu \mathrm{g} / \mathrm{mL}$ respectively.

Earlier work by Pardo (2003) also reported that inactive biomass of Pseudomonas putida has bio-sorption potentials for heavy metals. Similar studies involving the removal of Copper ions in effluent by $P$. putida, showed that $P$. putida have the capacity to remove over $80 \%$ of copper ions in copper contaminated wastewater. Results similar to this were also obtained from a study where Trametes versicolor were studied for their metal remediation properties, it was reported that copper ions, Lead ions, and Zinc ions were removal (Gulay,2003), Bacillus has been reported to effectively remove chromium (Shukla, 2007; Gulay, 2003), in another report, Funaliatrogii was found to have biosorption potential for Mercury, cadmium, and Zinc ion (Selvaraj, 2003), while Bacillus firmus can bio-absorb Lead, Copper, and Zinc (Salehizadeh, 2003).

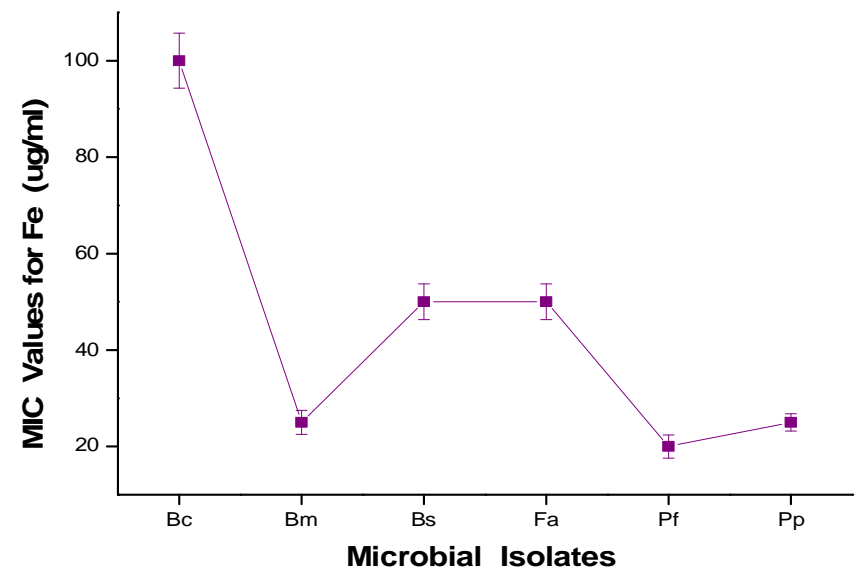

Fig. 3: MIC values of microbial isolates to aqueous salts of $\mathrm{Fe}_{2} \mathrm{SO}_{4}$

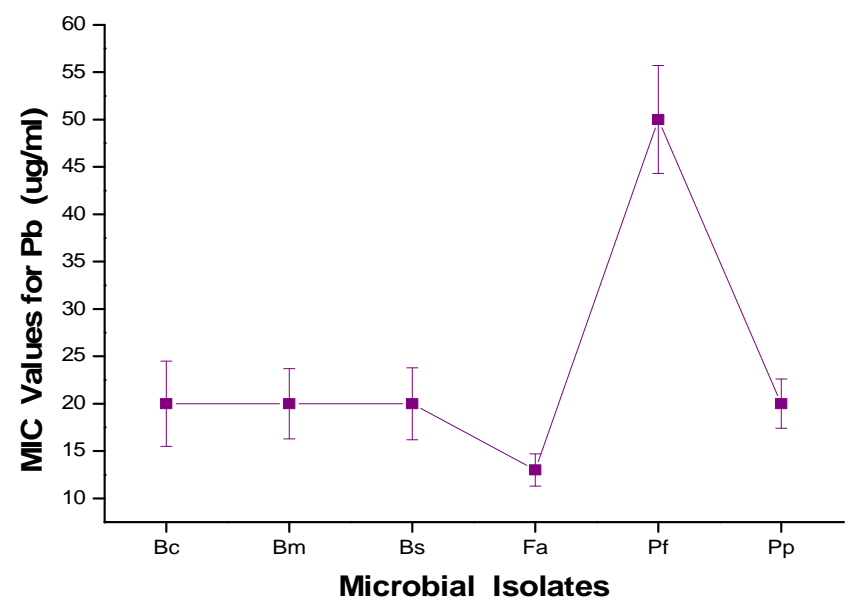

Fig. 4: MIC values of microbial isolates to aqueous salts of $\mathrm{Pb}_{2} \mathrm{SO}_{4}$

In general, micro-organisms uptake these metals either actively (bioaccumulation) or passively (bio-sorption). This is can be linked to bacteria surfaces affinity to metals ions resulting to their metal adsorbing and precipitating abilities. All these information discussed coupled with the result of this study clearly indicate that isolated bacteria like Bacillus cereus, Bacillus megaterium, Bacillus subtilis, Flavobacterium aquatile, Pseudomonas flourescens, Pseudomonas putida has proven to be a good development for efficient bio-sorbent for the removal and recovery of heavy metals.

\subsection{Conclusion}

Isolated microbes from this work such as; Bacillus cereus, Bacillus megaterium, Bacillus subtilis, Flavobacterium aquatile, Pseudomonas flourescens, and $P$. putida showed significant tendencies for use in metal-toxicity reduction and remediation processes. 


\subsection{Conflict Of Interest}

All Authors have declared no conflict of interest.

\section{Authors Contribution}

ONM designed the experiment

EAA provided the data

AA and LE were involved in the discussion of results

\section{References}

Alloway, B.J., 1995, Heavy metal in soils, Second edition. Chapman and Hall, London.

Ansari, T.M., Marr I.L and Tariq N., 2004, Heavy metals in marine pollution perspective- a mini review. J. Applied Sci., 4: 1-20.

APHA, AWWA, WEF, 1998, Standard methods for the examination ofwater and waste water. 20th American Public Health Association, American Water Works Association, WaterEnvironment Federation.

Benson, N.U., 2000, Lead, Nickel, Vanadium, Cobalt, and Manganese distributions in intensely cultivated flood plain of Cross River, Nigeria. Int. J. Soil Sci., 1: 140- 145

Cohen, D., (2005). Lead Poisoning in the environment and our children, URL; http.//www.links2health.com

Crawford, R.L and Crawford, D.L., 1995, Bioremediation: Principles and Applications. UK.Cambridge University Press.

Duxbury T., 1994, Toxicity of heavy metals to soil bacteria. FEMS Microbiology Letters; 11:2-3.

Gulay, B. B.,Sema, A and Yakup, M., 2003, Biosorption of heavy metal ions on immobilized whiterotfungus Trametes versicolor. Journal of Hazardous Materials, 101 (3): 285-300.

Hanif, M.A., Nadeem R., Rashid, U., Zafar, M.N., 2005, Assessing pollution levels in effluent of industries in city zone of Faisalabad, Pakistan J. Applied Sci., 5: 1713-1717.

Hassen, A., Saidi, N., Cherif, M., Boudabous, M., 1998, Resistance of environmental bacteria to heavy metal, Bioresources Technology; 64:7-15

Kadirvelu, K., Thamaraiselvi, K., $\quad$ Namasivayam, C., $\quad 2001$ b, Removal of heavy metals fromindstrial wastewaters by adsorption on to activated carbon prepared from an agricultural solid waste, Bioresource Technology, 76: 63-65.

Kao, W.C, Huang, C.C., Chang, J.S., 2008, Bioabsorption of nickel, chromium and zinc by MerP-expressing recombinant Escherichia coli. Journal of Hazardous Materials, 58 (1):100-106.

Lazarova V, H., Bouwer., Bahri, A. 2005, Water quality consideration, In: V. Lazarova and A. Bahri (eds), Water Reuse for Irrigation: Agriculture, Landscapes and Turf Grasses, CRC Press, Boca Raton, FL

Lin, C.C., Lin, H.L., 2005, Remediation of soil contaminated with the heavy metal $\left(\mathrm{Cd}^{2+}\right)$.Journal of Hazardous Materials, $122(1-2)$ : 7- 15.

Munoz, R., Alvarez, M.T., Munoz, A., Terrazas, E., Guieysse, B., Mattiasson, B., 2006, Sequential removal of heavy metals ions and organic pollutants using an algal-bacterial consortium.Chemosphere, 63: 903-911.
Nriagu, J.O., Pacyna, J.M., 1988, Quantitative assessment of worldwide contamination of air,water and soils by trace metals. Nature, 333: 134-139.

Nriagu, J.O., 1988, A silent epidemic of environmental metal poisoning, Environmental Pollution, 50: 139-161

Pardo, R, Herguedas, M, Barrado, E. Vega, M., 2003, Bio-sorption of cadmium, copper, lead and zinc by inactive biomass of Pseudomonas putida, Analytical and Bio-analytical Chemistry, 376: 26-32.

Peakall, D., 1992, Animal Biomarkers as Pollution Indicators, Chapmall and Hall, London,

Pandi, M., Shashirekha, V., Swami, M., 2009, Bioabsorption of chromium from retan chrome liquor by Cyanobacteria. Microbiological Research, 164 (4): 420-428.

Panikar, K.M., Pethkal, A.V and Puranik P.R., 2003, Bioremediation of metalliferous wastes and products using inactivated microbial biomass, Indian Journal of Biotechnology,2: 426-443

Rani, A., Goel., 2009, Microbial strategies for crop improvement, Springer, Berlin; 105-132.

Salehizadeh, H., Shojaosadati,S.A., 2003, Removal of metal ions from aqueous solution bypolysaccharide produced from Bacillus firmus. Water Research, 37 (17): 4231- 4235.

Saxena. M.M., 1998, Environmental Analysis: Water, Soil and Air. AgroBotanical Publishers, India.

Selvaraj, K., Manonmani. S., Pattabi, S., 2003, Removal of hexavalent chromium using distillerysludge. Bioresource Technology, 89 (3): 207-211

Shukla, O.P., Rai,U.N. Singh, N.K. Dubey, S. and Baghel, V.S., 2007, Isolation andcharacterization of chromate resistant bacteria from tannery effluent. Journal ofEnvironmental Biology, 28 (2): 399-403.

Umrania, V.V., 2006, Bioremediation of toxic heavy metals using acid othermophilic autotrophes.Bioresource Technology, 97: 1237- 1242.

Vullo, D.L., Ceretti, H.M. Hughes, E.A.,Ramırez,S., Zalts,A., 2005, Indigenous heavy metalmultiresistant microbiota of Las Catonas stream. Environmental Monitoring andAssessment, 105 (1-3): 81-97.

Wang, J.L., Chen,C., 2006, Biosorption of heavy metals by Saccharomyces cerevisiae: a review. Biotechnology Advances, 24 (5): $427-51$. 